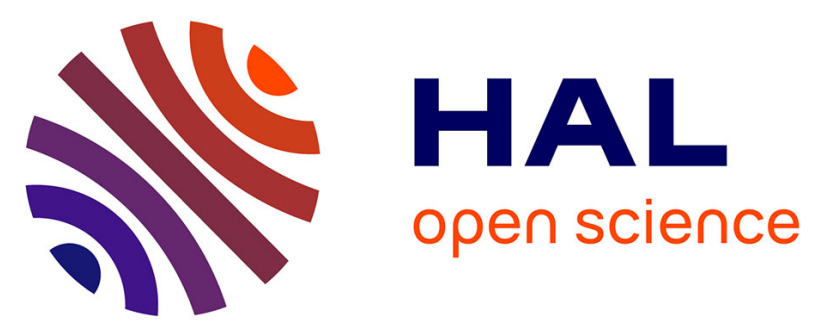

\title{
CLIPI: a new prognostic index for indolent cutaneous B cell lymphoma proposed by the International Extranodal Lymphoma Study Group (IELSG 11)
}

Michael Mian, Luigi Marcheselli, Stefano Luminari, Massimo Federico, Maria Cantonetti, Andreas H. Sarris, Andrea Rossi, Alessandro Rambaldi, Marina Frontani, Liliana Devizzi, et al.

\section{To cite this version:}

Michael Mian, Luigi Marcheselli, Stefano Luminari, Massimo Federico, Maria Cantonetti, et al.. CLIPI: a new prognostic index for indolent cutaneous B cell lymphoma proposed by the International Extranodal Lymphoma Study Group (IELSG 11). Annals of Hematology, 2010, 90 (4), pp.401-408. 10.1007/s00277-010-1083-1 . hal-00583543

\section{HAL Id: hal-00583543 https://hal.science/hal-00583543}

Submitted on 6 Apr 2011

HAL is a multi-disciplinary open access archive for the deposit and dissemination of scientific research documents, whether they are published or not. The documents may come from teaching and research institutions in France or abroad, or from public or private research centers.
L'archive ouverte pluridisciplinaire HAL, est destinée au dépôt et à la diffusion de documents scientifiques de niveau recherche, publiés ou non, émanant des établissements d'enseignement et de recherche français ou étrangers, des laboratoires publics ou privés. 
CLIPI: A NEW PROGNOSTIC INDEX FOR INDOLENT CUTANEOUS B-CELL LYMPHOMA PROPOSED BY THE INTERNATIONAL EXTRANODAL LYMPHOMA STUDY GROUP (IELSG 11)

Michael Mian ${ }^{1,2}$, Luigi Marcheselli ${ }^{3}$, Stefano Luminari ${ }^{3}$, Massimo Federico ${ }^{3}$, Maria Cantonetti ${ }^{4}$, Andreas H. Sarris ${ }^{5}$, Andrea Rossi ${ }^{6}$, Alessandro Rambaldi ${ }^{6}$, Marina Frontani ${ }^{7}$, Liliana Devizzi ${ }^{8}$, Alessandro Massimo Gianni ${ }^{9}$, Mario Busetto ${ }^{10}$, Emilio Berti ${ }^{11}$, Giovanni Martinelli $^{12}$, Richard W. Tsang ${ }^{13}$, Andrés J.M. Ferreri ${ }^{14}$, Graziella Pinotti ${ }^{15}$, Enrico Pogliani $^{16}$, Emanuele Zucca ${ }^{17}$ and Sergio Cortelazzo ${ }^{1}$.

${ }^{1}$ Division of Hematology, Azienda Ospedaliera S. Maurizio, Bolzano/Bozen, Italy

${ }^{2}$ Laboratory of Experimental Oncology and Lymphoma Unit, Oncology Institute of Southern Switzerland (IOSI), Bellinzona, Switzerland;

${ }^{3}$ Department of Oncology and Hematology, University of Modena and Reggio Emilia, Modena, Italy

${ }^{4}$ Chair of Hematology, Universita Tor Vergata, Rome, Italy

${ }^{5}$ Hematology, Hygeia Hospital \& Harvard Medical International, Athens, Greece.

${ }^{6}$ Division of Hematology, Ospedali Riuniti, Bergamo, Italy

${ }^{7}$ III Division of Dermatology, Istituto Dermopatico dell'Immacolata

IRCCS, Rome, Italy

${ }^{8}$ Medical Oncology 3 and Bone Marrow Transplantation Unit, Fondazione Istituto Nazionale per lo studio e la cura dei Tumori, Milan, Italy

${ }^{9}$ Medical Oncology 3 and Bone Marrow Transplantation Unit, Fondazione Istituto Nazionale per lo studio e la cura dei Tumori, Chair of Oncology, University of Milan, Italy

${ }^{10}$ Department of Radiotherapy, Sezione Oncoematologica, Ospedale Umberto I, Mestre (VE), Italy

${ }^{11}$ Chair of Dermatology, University of Milan 'Bicocca', Milan, Italy

${ }^{12}$ Division of Haematology, European Institute of Oncology, Milan, Italy

${ }^{13}$ Department of Radiation Oncology, University of Toronto, Princess Margaret Hospital, Toronto, Canada

${ }^{14}$ Unit of Lymphoid Malignancies, San Raffaele Scientific Institute, Milan, Italy

${ }^{15}$ Oncology, Varese, Italy

${ }^{16}$ Chair of Hematology, Milan-Bicocca, Italy

${ }^{17}$ Oncology Institute of Southern Switzerland, Bellinzona, Switzerland

Corresponding author: Michael Mian

Department of Hematology, Hospital of Bolzano

Via Lorenz Böhler 5

39100 Bolzano, Italy

Telephone: +390471908807

Fax: +390471908703

Mail: michael_mian@maxxisite.com 


\section{ABSTRACT}

Indolent primary cutaneous B-cell lymphomas (PCBCL) generally have a good prognosis, but they often relapse leading in some cases to extracutaneous disease and therefore to poor survival. We developed a prognostic model, to improve the therapeutic approach to these lymphomas.

217 patients with diagnosis of indolent PCBCL stage IE or IIE were assessed retrospectively. The prognostic model was built to fit a Cox proportional hazard model using all the covariates affecting PFS at $p<0.1$ in the univariate analysis and the final model was selected based on the Bayes Information Criteria.

Elevated serum lactate dehydrogenase, morphology of the lesion (nodule vs. other), and $>2$ lesions were independent predictors for PFS. To each prognostic factor was assigned a value of 1 . Patients were then stratified to three risk groups: score $0(28 \%)$, low risk; score 1 (55\%), intermediate risk; score 2 and 3 (17\%), high risk with a 5-year PFS of $91 \%, 64 \%$, and $48 \%$, respectively $(\mathrm{p}<0.001)$.

The CLIPI is an easily applicable prognostic index and represents a promising tool for risk adapted treatment strategies. However, it needs to be addressed in prospective clinical studies.

Keywords: B-cell, CLIPI, cutaneous, lymphoma, prognostic index 


\section{INTRODUCTION}

Primary cutaneous B-cell lymphomas (PCBCL) are a distinct group of B-cell non-Hodgkin lymphomas (NHL), which present exclusively in the skin and have different characteristics than their nodal counterparts[1]. They are a rare disease accounting for less than $25 \%$ of all primary cutaneous NHL and are generally associated with a good prognosis [2]. For many years the classification of these diseases was not clear since two different systems were in use, the World Health Organization (WHO) and the European Organisation for Research and Treatment of Cancer (EORTC) classifications [2,3]. In 2005 the WHOEORTC classification for cutaneous lymphomas [1] was introduced, subdividing PCBCL in three entities: primary cutaneous marginal zone B-cell lymphoma (PCMZL), primary cutaneous follicle center lymphoma (PCFCL) and primary cutaneous large B-cell lymphoma, leg type (PCLBCL, LT). The latter are highly aggressive and lead to death in estimated $50 \%$ of the cases after 5 years [1,4], while PCFCL and PCMZL are characterized by an indolent clinical course with a 5 year overall survival (OS) $495 \%$. However, these lymphomas have a relapse rate between $20 \%$ and $60 \%$ according to different studies [5-11]. Nevertheless, since relapses are mainly confined to the skin and they do not constitute a dissemination of disease, the standard of care in patients without extensive cutaneous disease or evidences of Borrelia burgdorferi infection, consists of local treatments, namely surgical excision (SX) or radiotherapy (RT) [4]. However, it has been shown that extracutaneous relapses can occur in $8-10 \%$ [12], leading to a dismal outcome and therefore more aggressive treatments could be needed. Since the median age of the patients affected by PCFCL and PCMZL is below 60 years of age at time of diagnosis and the majority has a prolonged survival it is crucial to identify poor-risk patients at time of diagnosis, in order to develop risk adapted treatment strategies. Several efforts for the detection of prognostic parameters were undertaken and the most promising seems to be involvement of the lower extremities, especially in PCFCL $[8,9,12-14]$. 
However, three of this trials $[14,13,8]$ included all PCBCL subtypes and analyses of the subgroups were not, or only partially performed. Therefore, the results were mainly focused on the poor risk of PCLBCL,LT. The international extranodal lymphoma study group (IELSG) conducted this study (IELSG-23) in order to develop a model for predicting the clinical course of patients affected by PCFCL and PCMZL.

\section{MATERIALS \& METHODS}

\section{PATIENTS}

Two-hundred and seventeen patients with diagnosis of PCBCL from 28 international cancer centers were assessed through retrospective chart review. PCBCL were defined according to the WHO-EORTC classification [1] as PCFCL and PCMZL, which presented primarily as skin tumors without any involvement at other sites (stage IE or IIE). Morphology was reviewed by an expert of each participating center and all unclear cases centrally by an ad hoc expert panel. Diagnoses stated before 2005 were converted into the categories of the WHO-EORTC classification for cutaneous lymphomas. All centers contributing patients had approval of the study from the hospital's institutional review board in accordance with the declaration of Helsinki.

Staging procedures included complete physical examination with assessment of the performance status [15], skin biopsy or surgical excision of the lesion, and computed tomography (CT) of thorax, abdomen and pelvis. Since in the early 1980 s not all centers were equipped with a CT device, ultrasonography was used in some cases. In order to exclude a stage IV disease, the majority of the patients underwent bone marrow biopsy. Stage was assessed according to the Ann Arbor classification modified by Musshoff [16]. Although all requested information was available, extent of disease was not measured 
according to the recently published TNM system[17], since it combines several clinical factors such as number of lesions and diameter of disease, which could have a different impact on progression free survival (PFS).

Patients were treated according the extent of disease, following the standards of the participating centers. Therefore patients with localized disease underwent local treatment modalities (LT), consisting of RT, SX or both, whereas cases with regional or disseminated disease underwent either chemotherapy $(\mathrm{CHT})$ alone or in combination with LT. However, since the patients were assessed retrospectively in different institutions, there was no uniform treatment policy and some patients with localized disease underwent CHT.

\section{STATISTICAL ANALYSIS}

The study strove to develop of a simple prognostic scoring system easily applicable in the clinical routine without the need of extensive diagnostics.

Comparisons between clinical parameters were made by means of Fisher's exact test when appropriate or chi-square test. Response was assessed after the completion of the treatment. Complete remission $(\mathrm{CR})$, partial remission $(\mathrm{PR})$, stable disease $(\mathrm{SD})$ and progressive disease (PD) as well as OS, progression free survival (PFS) and disease-free survival (DFS) were defined according to the criteria by Cheson et al [18]. The actuarial duration of OS, PFS and DFS were plotted as curves according to the Kaplan-Meier [19] method.

The LDH level was categorized according to the previous published threshold value. Otherwise, for continuous covariates the cut-off values were obtained by comparing distribution quartiles using the log-rank test, whereas categorical covariates were dichotomized comparing the Kaplan-Meier curves by means of log-rank test. Since we considered only patients affected by indolent PCBCL (PCFCL and PCMZL) for the development of the score and since they usually have a favorable clinical course leading 
to a low death rate, the prognostic score was developed according to PFS [20], reflecting tumor growth and not being confounded by the administration of subsequent treatments. Afterwards we applied the score on OS and DFS. For determination of the most significant variables contributing to survival, univariate analysis was performed with the log-rank test [21]. Multiple test correction was not done, because this method was applied to discard parameters without a significant impact. In the next step a prognostic model was built to fit a Cox proportional hazard model [22] using all the covariates affecting PFS at $p<0.1$ in the univariate analysis and the final model was selected based on the Bayes Information Criteria proposed by Raftery-Volinsky (BIC'), as a measure of overall fit. We chosen the model with the more negative BIC [23]. The proportionality of the risks and overall model fit were graphically checked using scaled Schoenfeld [24] and Cox-Snell residuals; overfitting (shrinkage factor) and the performance of the model were checked using Harrell's method [25]. The scoring system was confirmed with the log-rank test and the Harrell's concordance index (C-Harrell) [26]. All p-values were based on two-sided testing.

A $p<0.05$ was considered to demonstrate a moderate strength against the null hypothesis. All statistical analyses were performed with Stata Statistical Software release 8.0 (StataCorp, College Station, TX) and PASW Statistics v17.02 (SPSS, Chicago, IL, USA).

\section{RESULTS}

\section{PATIENTS CHARACTERISTICS AND TREATMENTS}

From 1980 to 2007, 217 patients with indolent PCBCL stage IE or IIE were assessed. Patient characteristics at time of diagnosis are listed in Table 1. The median age was 55 years (range, 18-91 years) and a male predominance (m:f=1.57) was observed. Less than one third of the patients presented with regional or generalized disease (66 patients, 30\%), stage IIE was present in 20\% (43 patients) and nodular lesions prevailed (142, 65\%). No statistical significant differences were observed between FCL and MZL, except in the 
number of lymphomas occurring on lower extremities ( $7 \%$ in FCL versus $16 \%$ in MZL, $\mathrm{p}=0.003)$. Patients received CHT $(40 / 217,18 \%)$, RT $(87 / 217,40 \%)$ or SX alone $(37 / 217$, $17 \%)$ or a combination of CHT and/or RT $(53 / 217,25 \%)$. In $66 \%$ of the cases $(65 / 98)$ chemotherapy consisted of an anthracycline-containing regimen. Only two patients received rituximab. Overall, 198 patients (91\%) achieved CR, $16(8 \%)$ a PR and only 3 patients $(1 \%)$ did not respond to treatment, in two cases due to PD and in another two due to SD. After a median follow up of 55 months (range 2 - 244 months) 54 patients (27\%) relapsed: $37(19 \%)$ locally, $10(5 \%)$ at distant cutaneous sites or with a disseminated but disease confined to the skin and $7(3 \%)$ with extracutaneous lymphoma. Notably, the majority of recurrences occurred in patients with primary localized disease (34 patients, $63 \%$ ). Eight of ten distant cutaneous recurrences as well as all extranodal relapses, were observed within this subgroup of patients. The relapse rate did not differ significantly among the different treatment modalities $(p=0.058)$, but the percentage of relapse was $17 \%$ in the group which underwent combined treatment modalities vs. $31 \%$ in the other. Eighteen patients died (3.7\%): 11 due to disease, 2 of second tumor an 4 for other causes. The majority of lymphoma related deaths (8 cases) were observed in patients who relapsed after primary localized disease. The 5-year OS, PFS and DFS were $90 \%$ (median not reached), 68\% (median 139 months), 69\% (median 145 months), respectively (Fig 1). The different treatment modalities did not influence PFS significantly (data not shown), even when analyzed according to the extend of disease (Supplementary Fig 1).

\section{DEVELOPMENT OF THE PROGNOSTIC MODEL}

In order to identify the most important parameters influencing the PFS, univariate analysis

was performed. Sixty events were observed: 54 relapses, 7 disease progressions (11\%), two deaths in $\mathrm{CR}(3 \%)$ and one lymphoma related death (2\%). Eleven variables were 
analysed and six variables had a $p<0.1$ : age $>65$ years $(p=0.04)$, male sex $(p=0.156)$, serum lactate dehydrogenase $(\mathrm{LDH})>$ upper normal limit $(\mathrm{UNL} ; \mathrm{p}<0.001)$, morphology of lesion (nodule or not; $p<0.001)$, locoregional distribution vs. generalized disease $(p=0.151)$ and more than 2 lesions $(p=0.004)$ (Supplementary Table). Subsequently we built a prognostic model to fit a Cox proportional hazard model. We chose the model with the best overall fit in terms of $\mathrm{BIC}$. Although the hazard ratio $(\mathrm{HR})$ differed among the single factors, the standard errors were approximately proportional (Table 2). Variables with independent prognostic value were LDH serum level, number of lesions and nodular lesions. Therefore, we constructed a risk score by summing the number of factors present in a single patient without weights. Risk groups were defined by comparing the relative risk of disease progression in patients with each possible number of presenting prognostic factors and combining the categories with a similar relative risk. Then, patients were stratified according to the following three risk groups: score $0(28 \%)$, low risk (LR); score 1 (55\%), intermediate risk (IR); score 2 and $3(17 \%)$, high risk (HR) (Table 3$)$. According to the different scores, 5-years PFS was $91 \%, 64 \%$, and $48 \%$ for patients at LR, IR, and HR, respectively $(p<0.001)$. CLIPI was also highly predictive for DFS $(p<0.001)$, whereas the impact on OS was not significant $(p=0.449)$.

The CLIPI was also predictive for each of the two indolent lymphoma categories included in this study when applied to PFS and DFS. Interestingly, among MZL the ability to discriminate patients with poorer survival was not significant $(p=0.350)$, whereas among FCL the score was able to stratify the risk groups, although we did not refute the null hypothesis with enough strength $(p=0.091)$ (Supplementary Fig 2).

\section{DISCUSSION}


This retrospective multi-center study was conducted to develop a prognostic score for indolent PCBCL. It consists of elevated LDH serum level, number of cutaneous lesions and nodular lesions, and constitutes an easy and useful tool to distinguish three prognostic subgroups. The 5-yr PFS was $91 \%, 64 \%$ and $48 \%$ respectively for patients with low, intermediate and high risk according to the CLIPI.

The main limits of this study were the retrospective assessment of the patients, the long time period of data collection and the lack of a statistically significant impact of the score on OS. The first two limits were due to the rarity of this disease, whereas the last one could be ascribed to the generally indolent course of this PCBCL and efficient salvage treatments [4].

Baseline clinical characteristics, outcome and survival of our cohort reflected those of previously published series $[13,12,1]$. We observed no statistical significant differences in terms of clinical characteristics and survival between the two indolent subtypes PCMZL and PCFCL.

In univariate analysis six factors had a $p<0.2$ and were therefore included in the development of the prognostic score. After multivariate analysis only elevated LDH, morphology of the lesion and $>2$ lesions constituted the CLIPI.

Already Zinzani et al [13] showed that among indolent PCBCL the presence of more than one lesion influences the DFS negatively. Of note, among the different parameters which contribute to the TNM system [17], this is the only one with an independent impact on PFS in this setting of patients.

The prognostic role of the morphology of the lesion (nodular or not), has not been evaluated yet in previous trials. Nevertheless, already in univariate analysis it emerged as one of the most important factors influencing the PFS of indolent PCBCL. As shown in Supplementary Fig 3, the PFS of patients with nodular lesions is highly influenced by the type of treatment and only anthracycline-containing chemotherapy was able to improve the 
outcome. This suggests that, albeit these NHL have a tendency to remain localized to a limited area of the skin [7], neoplastic cells could infiltrate the surrounding tissue deeply, leading to a higher relapse rate.

Despite the CLIPI was developed according to PFS, we demonstrated that it is applicable to DFS; when applied to OS no statistical significance was observed, although there seems to be a slight impact in FCL. The majority of relapses occurred in patients with primary localized disease, leading to a lymphoma related death in 8 cases. Certainly the relapse rate and the severity of the recurrences observed in this study might be underestimated since $40 \%$ of the patients with localized disease underwent CHT, which in $80 \%$ contained anthracyclines. Nevertheless, our results suggest that probably, mostly due to the rather indolent course of this NHLs, their aggressiveness gets underestimated in some cases, causing not only recurrence of disease, but also a dismal survival. Indeed, a large trial of 153 patients affected by PCBCL and solely treated with $R T$, it has been shown that, despite indolent PCBCL being considered as highly radiosensitive (CR rate of $100 \%)$, the relapse rate is rather high and extranodal disease can occur[10]. Since the CLIPI is able to identify poor-risk patients at time of diagnosis, it constitutes a useful tool to provide risk adapted treatment strategies and to avoid unnecessary toxicity. Therefore, in patients with high-risk CLIPI, even if they have primary localized disease, alternative treatment modalities should be considered.

In conclusion, the IELSG-23 trial confirms that indolent PCBCL have a significant rate of distant relapses which can be reliably predicted by several clinical features, and these can be assembled together to provide a strong prognostic index. The CLIPI is able to discriminate patients with low, intermediate and high risk disease allowing the development of risk adapted treatments. This prognostic model does not require extensive diagnostics and is therefore easy to use in clinical practice. However, prospective studies are warranted to validate the clinical role of CLIPI in patients with indolent PCBCL. 


\section{ACKNOWLEDGEMENTS}

The authors thank Ivo Kwee, Wolfgang Weiss, Andrea Piccin for providing advice and Giuseppe Lombardo, Felice Pasini, Osnat Bairey, Silvia Rudoy, Robert Blum for providing patient data. This work was supported by Bolzano-AIL Onlus. 


\section{References}

1. Willemze R, Jaffe ES, Burg G, Cerroni L, Berti E, Swerdlow SH, Ralfkiaer E, Chimenti S, Diaz-Perez JL, Duncan LM, Grange F, Harris NL, Kempf W, Kerl H, Kurrer M, Knobler R, Pimpinelli N, Sander C, Santucci M, Sterry W, Vermeer MH, Wechsler J, Whittaker S, Meijer CJ (2005) Who-eortc classification for cutaneous lymphomas. Blood 105 (10):3768-3785. doi:2004-09-3502 [pii]

10.1182/blood-2004-09-3502

2. Willemze R, Kerl H, Sterry W, Berti E, Cerroni L, Chimenti S, Diaz-Perez JL, Geerts ML, Goos M, Knobler R, Ralfkiaer E, Santucci M, Smith N, Wechsler J, van Vloten WA, Meijer CJ (1997) Eortc classification for primary cutaneous lymphomas: A proposal from the cutaneous lymphoma study group of the european organization for research and treatment of cancer. Blood 90 (1):354-371

3. Jaffe E, Harris N, Stein H, Vardiman J (2001) Pathology and genetics of tumors of haematopoietic and lymphoid tissues. World health organization (who) classification of tumors. World Health Organization, Lyon

4. Senff NJ, Noordijk EM, Kim YH, Bagot M, Berti E, Cerroni L, Dummer R, Duvic M, Hoppe RT, Pimpinelli N, Rosen ST, Vermeer MH, Whittaker S, Willemze R, European Organization for Research and Treatment of Cancer, International Society for Cutaneous Lymphoma (2008) European organization for research and treatment of cancer and international society for cutaneous lymphoma consensus recommendations for the management of cutaneous b-cell lymphomas. Blood 112 (5):1600-1609. doi:10.1182/blood-2008-04-152850

5. Garcia CF, Weiss LM, Warnke RA, Wood GS (1986) Cutaneous follicular lymphoma. Am J Surg Pathol 10 (7):454-463

6. Pimpinelli N, Santucci M, Carli P, Paglierani M, Bosi A, Moretti S, Giannotti B (1990) Primary cutaneous follicular center cell lymphoma: Clinical and histological aspects. Curr Probl Dermatol 19:203-220

7. Santucci M, Pimpinelli N, Arganini L (1991) Primary cutaneous b-cell lymphoma: A unique type of low-grade lymphoma. Clinicopathologic and immunologic study of 83 cases. Cancer 67 (9):2311-2326

8. Grange F, Hedelin G, Joly P, Beylot-Barry M, D'Incan M, Delaunay M, Vaillant L, Avril MF, Bosq J, Wechsler J, Dalac S, Grosieux C, Franck N, Esteve E, Michel C, Bodemer C, Vergier B, Laroche L, Bagot M (1999) Prognostic factors in primary cutaneous lymphomas other than mycosis fungoides and the sezary syndrome. The french study group on cutaneous lymphomas. Blood 93 (11):3637-3642

9. Grange F, Bekkenk MW, Wechsler J, Meijer CJ, Cerroni L, Bernengo M, Bosq J, Hedelin G, Fink Puches R, van Vloten WA, Joly P, Bagot M, Willemze R (2001) Prognostic factors in primary cutaneous large b-cell lymphomas: A european multicenter study. J Clin Oncol 19 (16):3602-3610

10. Senff NJ, Hoefnagel JJ, Neelis KJ, Vermeer MH, Noordijk EM, Willemze R (2007) Results of radiotherapy in 153 primary cutaneous b-cell lymphomas classified according to the who-eortc classification. Arch Dermatol 143 (12):1520-1526. doi:143/12/1520 [pii]

10.1001/archderm.143.12.1520

11. Smith BD, Glusac EJ, McNiff JM, Smith GL, Heald PW, Cooper DL, Wilson LD (2004) Primary cutaneous b-cell lymphoma treated with radiotherapy: A comparison of the european organization for research and treatment of cancer and the who classification systems. J Clin Oncol 22 (4):634-639. doi:10.1200/JCO.2004.08.044 JCO.2004.08.044 [pii]

12. Senff NJ, Hoefnagel JJ, Jansen PM, Vermeer MH, van Baarlen J, Blokx WA, Canninga-van Dijk MR, Geerts ML, Hebeda KM, Kluin PM, Lam KH, Meijer CJ, Willemze R (2007) Reclassification of 300 primary cutaneous b-cell lymphomas 
according to the new who-eortc classification for cutaneous lymphomas:

Comparison with previous classifications and identification of prognostic markers. $J$

Clin Oncol 25 (12):1581-1587. doi:JCO.2006.09.6396 [pii]

10.1200/JCO.2006.09.6396

13. Zinzani PL, Quaglino P, Pimpinelli N, Berti E, Baliva G, Rupoli S, Martelli M, Alaibac M, Borroni G, Chimenti S, Alterini R, Alinari L, Fierro MT, Cappello N, Pileri A, Soligo D, Paulli M, Pileri S, Santucci M, Bernengo MG, Italian Study Group for Cutaneous Lymphomas (2006) Prognostic factors in primary cutaneous b-cell lymphoma: The italian study group for cutaneous lymphomas. J Clin Oncol 24 (9):1376-1382. doi:10.1200/JCO.2005.03.6285

14. Smith BD, Smith GL, Cooper DL, Wilson LD (2005) The cutaneous b-cell lymphoma prognostic index: A novel prognostic index derived from a population-based registry. J Clin Oncol 23 (15):3390-3395. doi:23/15/3390 [pii]

10.1200/JCO.2005.08.137

15. Oken MM, Creech RH, Tormey DC, Horton J, Davis TE, McFadden ET, Carbone PP, Zubrod (1982) Toxicity and response criteria of the eastern cooperative oncology group. Am J Clin Oncol 5 (6):649-655

16. Carbone PP, Kaplan HS, Musshoff K, Smithers DW, Tubiana M (1971) Report of the committee on hodgkin's disease staging classification. Cancer Res 31 (11):18601861

17. Kim YH, Willemze R, Pimpinelli N, Whittaker S, Olsen EA, Ranki A, Dummer R, Hoppe RT (2007) Tnm classification system for primary cutaneous lymphomas other than mycosis fungoides and sezary syndrome: A proposal of the international society for cutaneous lymphomas (iscl) and the cutaneous lymphoma task force of the european organization of research and treatment of cancer (eortc). Blood 110 (2):479-484. doi:blood-2006-10-054601 [pii]

10.1182/blood-2006-10-054601

18. Cheson BD, Horning SJ, Coiffier B, Shipp MA, Fisher RI, Connors JM, Lister TA, Vose J, Grillo-Lopez A, Hagenbeek A, Cabanillas F, Klippensten D, Hiddemann W, Castellino R, Harris NL, Armitage JO, Carter W, Hoppe R, Canellos GP (1999) Report of an international workshop to standardize response criteria for nonhodgkin's lymphomas. Nci sponsored international working group. J Clin Oncol 17 (4): 1244

19. Meier ELKaP (1958) Nonparametric estimation from incomplete observations. Journal of the American Statistical Association 53 (282):25

20. Cheson BD, Pfistner B, Juweid ME, Gascoyne RD, Specht L, Horning SJ, Coiffier B, Fisher RI, Hagenbeek A, Zucca E, Rosen ST, Stroobants S, Lister TA, Hoppe RT, Dreyling M, Tobinai K, Vose JM, Connors JM, Federico M, Diehl V, The International Harmonization Project on Lymphoma (2007) Revised response criteria for malignant lymphoma. J Clin Oncol 25 (5):579-586.

doi:10.1200/JCO.2006.09.2403

21. Mantel N, Haenszel W (1959) Statistical aspects of the analysis of data from retrospective studies of disease. J Natl Cancer Inst 22 (4):719-748

22. Cox DR (1972) Regression models and life-tables. Journal of the Royal Statistical Society 34 (2):34

23. Volinsky CT, Raftery AE (2000) Bayesian information criterion for censored survival models. Biometrics 56 (1):256-262

24. Schoenfeld D (1982) Partial residuals for the proportional hazards regression model. Biometrika 69 (1):239-241. doi:10.1093/biomet/69.1.239

25. Harrell FE, Lee KL, Mark DB (1996) Multivariate prognostic model: Issues in developing models, evaluating assumptions and adequacy, and measuring and reducing errors. Statistics in Medicine 15 (4):361-387 
26. Harrell FE, Jr., Califf RM, Pryor DB, Lee KL, Rosati RA (1982) Evaluating the yield of medical tests. JAMA 247 (18):2543-2546 


\section{FIGURE LEGENDS}

Fig 1. Overall survival, progression free survival and disease free survival of 217 patients used for Cutaneous B-cell lymphoma International Prognostic Index development.

Fig 2. PFS (A), DFS (B) and OS (C) of 217 patients according to CLIPI: low risk, score 0; intermediate risk, score 1; high risk, score 2-3. 


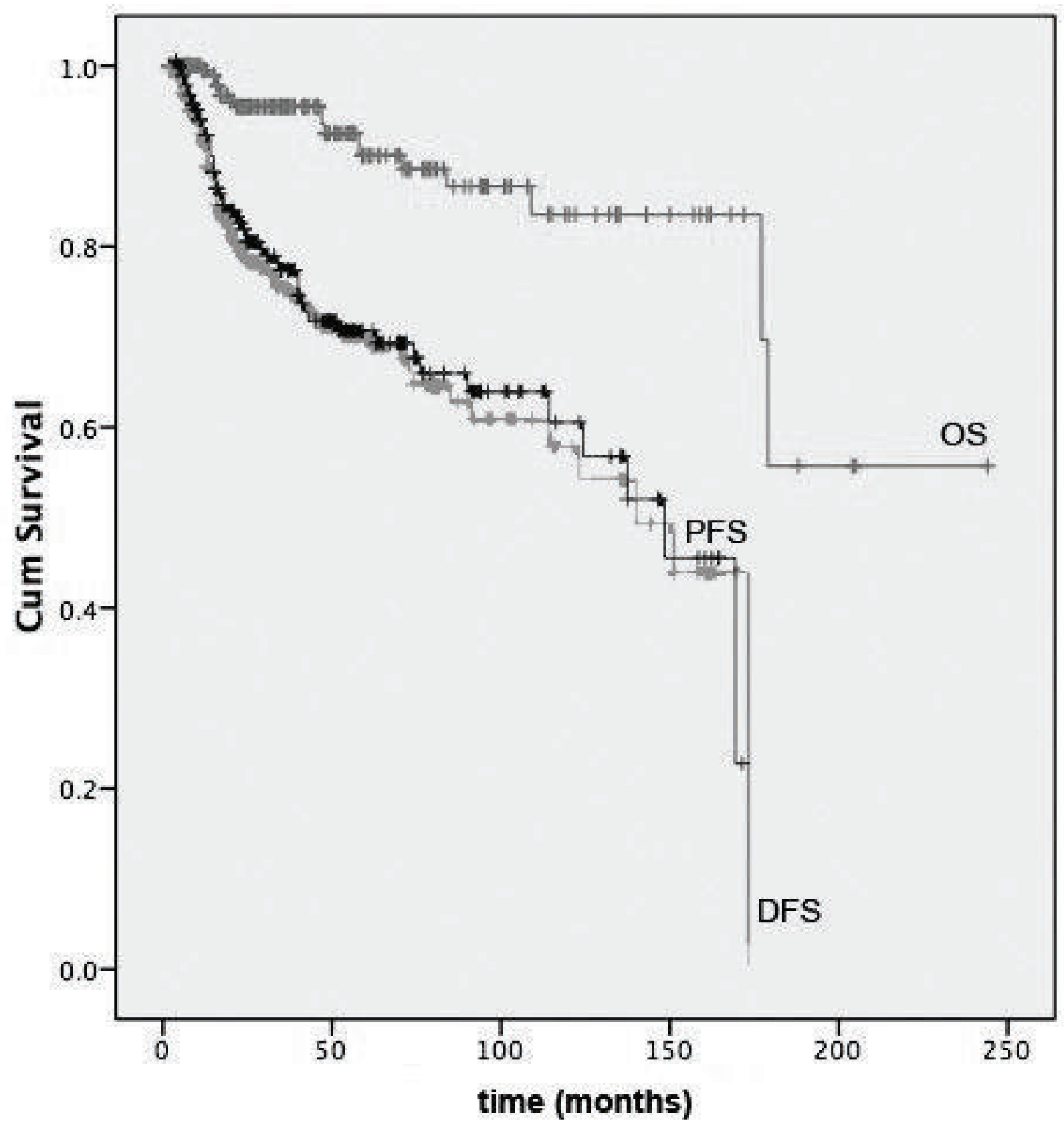




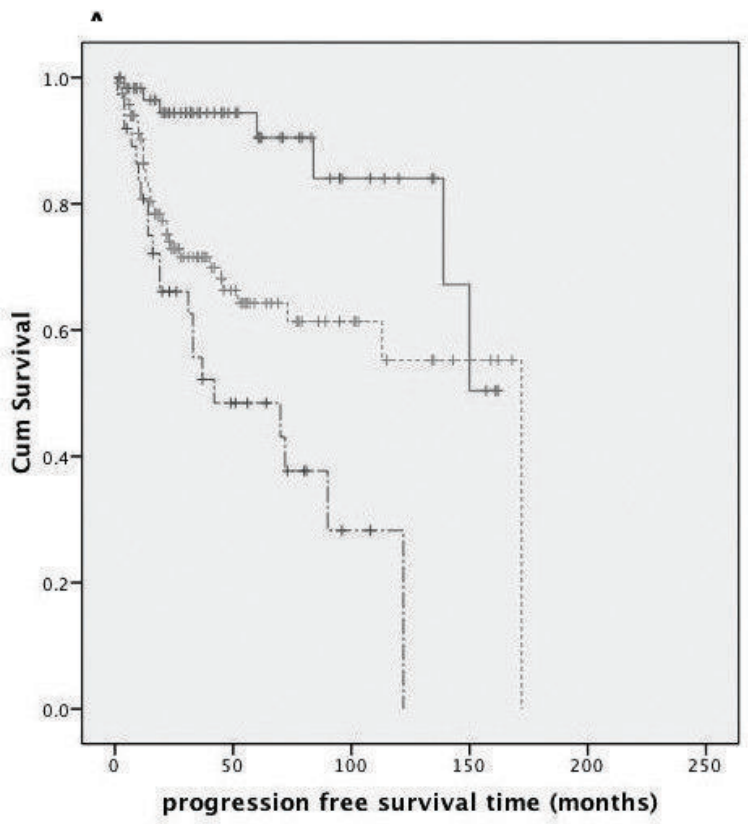

CLIPI

$\rightarrow$ score 0

-.-score 2 -3

+ score 0-censored

+ score 2-3-censored

B

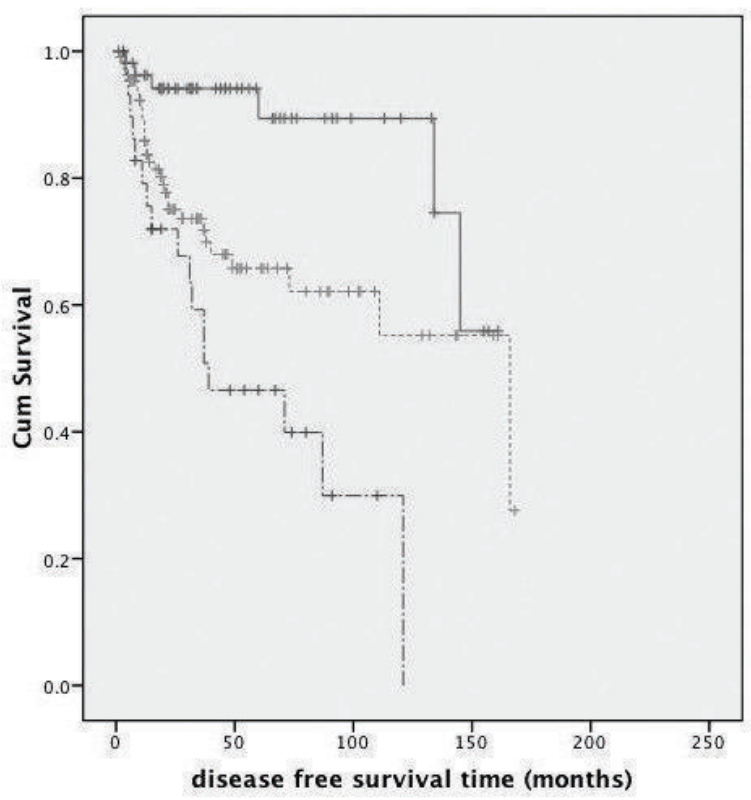

CLIP
$\rightarrow$ score 0 -..nscore 1 - score 2-3
+ score 0-censored + score 1-censored - score 2-3-censored

C

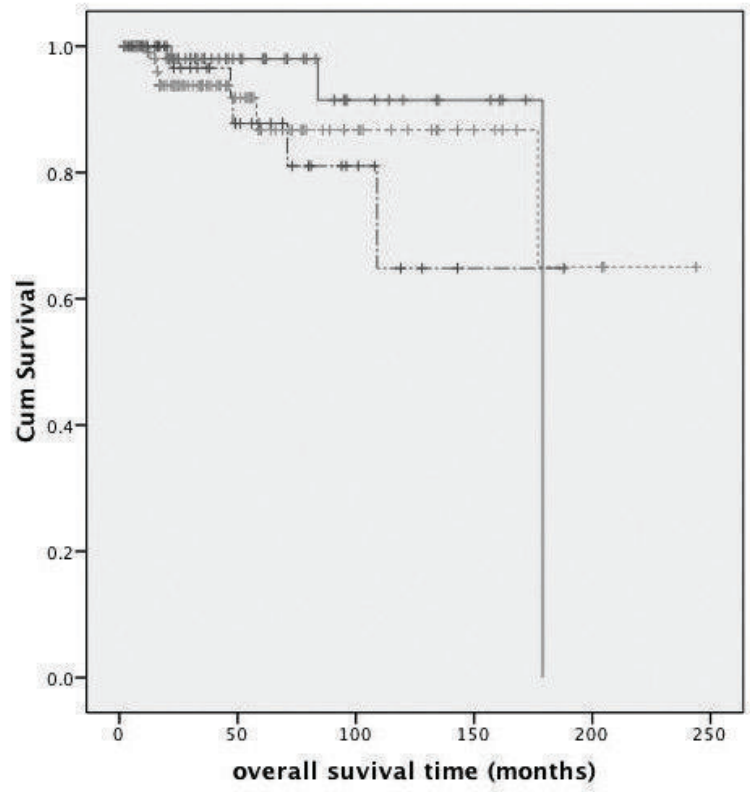

CLIPI

Tscore 0 - score 1 + score 0-censored + score 1-censored + score 2-3-censored 


\section{TABLE LEGENDS}

Table 1. Baseline characteristics of the assessable patients $(n=217)$.

Abbreviations: m, male; f, female; UNL, upper normal limit; RT, radiotherapy; SX, surgery; CHT, chemotherapy.

Table 2. Multivariate analysis of progression free survival (PFS). Slope shrinkage and c-Harrel obtained after 250 bootstrap replications. Abbreviations: HR, hazard ratio; SE, standard error.

Table 3. CLIPI score performance in progression free survival (PFS). 
TABLES

\begin{tabular}{|c|c|c|}
\hline Characteristic & No. & $\%$ \\
\hline $\begin{array}{l}\text { Median age, years } \\
\text { Range } \\
\leq 65 \text { years } \\
>65 \text { years }\end{array}$ & $\begin{array}{c}55 \\
18-91 \\
161 \\
56\end{array}$ & $\begin{array}{l}74 \\
26\end{array}$ \\
\hline Gender (m:f) & $131: 83$ & $62: 38$ \\
\hline $\begin{array}{l}\text { Site of disease } \\
\text { Head and neck } \\
\text { Trunk, upper extremities } \\
\text { Lower extremities } \\
\text { Generalized skin disease }\end{array}$ & $\begin{array}{c}65 \\
121 \\
16 \\
15\end{array}$ & $\begin{array}{l}30 \\
56 \\
7 \\
7\end{array}$ \\
\hline $\begin{array}{l}\text { Extent of cutaneous involvement } \\
\text { Local } \\
\text { Regional or generalized }\end{array}$ & $\begin{array}{c}151 \\
66\end{array}$ & $\begin{array}{l}70 \\
30\end{array}$ \\
\hline $\begin{array}{l}\text { Morphology of the lesion } \\
\text { Nodular } \\
\text { Other (plague, macule etc) }\end{array}$ & $\begin{array}{c}142 \\
75\end{array}$ & $\begin{array}{l}65 \\
35\end{array}$ \\
\hline $\begin{array}{l}\text { No. of lesions } \\
\text { Median (range) } \\
1-2 \\
>2\end{array}$ & $\begin{array}{c}1(1-80) \\
170 \\
47\end{array}$ & $\begin{array}{l}78 \\
22\end{array}$ \\
\hline $\begin{array}{l}\text { Ann Arbour stage } \\
\text { I E } \\
\text { II E }\end{array}$ & $\begin{array}{c}174 \\
43\end{array}$ & $\begin{array}{l}80 \\
20\end{array}$ \\
\hline $\begin{array}{l}\text { ECOG PS } \\
0-1 \\
>1\end{array}$ & $\begin{array}{c}178 \\
39\end{array}$ & $\begin{array}{l}82 \\
18\end{array}$ \\
\hline $\begin{array}{l}\text { Serum LDH } \\
\leq \text { UNL } \\
>\text { UNL }\end{array}$ & $\begin{array}{c}209 \\
8\end{array}$ & $\begin{array}{c}96 \\
4\end{array}$ \\
\hline $\begin{array}{l}\text { B-Symptoms } \\
\text { No } \\
\text { Yes }\end{array}$ & $\begin{array}{c}209 \\
8\end{array}$ & $\begin{array}{c}96 \\
4\end{array}$ \\
\hline $\begin{array}{l}\text { Treatment modalities } \\
\text { RT } \\
\text { SX } \\
\text { CHT } \\
\text { CHT + (RT or SX) }\end{array}$ & $\begin{array}{l}87 \\
36 \\
40 \\
54\end{array}$ & $\begin{array}{l}40 \\
17 \\
18 \\
25\end{array}$ \\
\hline
\end{tabular}

Table 1. 


\begin{tabular}{|l|c|c|c|c|c|c|c|}
\hline Covariate & $\begin{array}{c}\text { Adverse } \\
\text { Factor }\end{array}$ & $\begin{array}{c}\text { Patients } \\
\text { (\%) }\end{array}$ & 5yr PFS (\%) & \multicolumn{3}{|c|}{$\begin{array}{c}\text { Final Model } \\
\text { (N=217) }\end{array}$} & $\begin{array}{c}\text { Slope } \\
\text { shrinkage }\end{array}$ \\
\cline { 3 - 7 } & & & HR & SE & p & \\
\hline LDH & $>$ UNL & 4 & 12 & 3.40 & 1.42 & 0.003 & 0.913 \\
\hline \# Lesion & $>2$ & 22 & 55 & 1.76 & 0.48 & 0.038 & 0.939 \\
\hline $\begin{array}{l}\text { Nodular } \\
\text { lesion }\end{array}$ & positive & 55 & 59 & 2.63 & 0.89 & 0.004 & 0.914 \\
\hline Model & & & & & & & 0.914 \\
\hline c-Harrel & & & & & & & 0.662 \\
\hline
\end{tabular}

Table 2.

\begin{tabular}{|l|c|c|c|}
\hline \multirow{2}{*}{ Score } & \multicolumn{2}{|c|}{ Patients } & \multirow{2}{*}{ 5yr PFS (\%) } \\
\cline { 2 - 4 } & $\mathbf{N}$ & \% & \\
\hline 0 & 61 & 28 & 91 \\
\hline 1 & 119 & 55 & 64 \\
\hline $2-3$ & 37 & 17 & 48 \\
\hline Log-rank & & & $<0.001$ \\
\hline c-Harrel & & & 0.648 \\
\hline
\end{tabular}

\section{Table 3.}

